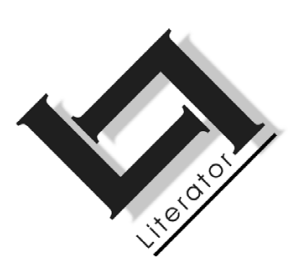

\title{
From foreign to national: a review of the status of the French language in Gabon ${ }^{1}$
}

\author{
H.S. Ndinga-Koumba-Binza \\ Centre for Text Technology (CTexT) \\ Potchefstroom Campus \\ North-West University \\ POTCHEFSTROOM \\ E-mail: 22602569@nwu.ac.za
}

\begin{abstract}
From foreign to national: a review of the status of the French language in Gabon
\end{abstract}

This article provides a review of the various statuses of the French language in Gabon, a French-speaking country in Central Africa. It reveals a process in which different generations of Gabonese people are increasingly learning, and thus conceptualising, French as a second language rather than a foreign language. Furthermore, some are also learning and conceptualising French as a mother tongue or initial language, rather than a second language. This process of reconceptualisation has somehow been encouraged by the language policy of the colonial administration and the language policy since the attainment of independence, the latter being a continuation of the former. The final stage of this process is that the language has been adopted among the local languages within the Gabonese language landscape.

1 This article was completed while the author was on a Coimbra Group Young Researchers Scholarship at the Centre for Lexicography, Aarhus School of Business, Aarhus University, Denmark. The author is grateful to Lauren Onraët for sound proofreading and insightful comments. The author is solely responsible for the content and any oversight to be found. 


\section{Opsomming}

\section{Van uitheems tot volkstaal: 'n oorsig van die status van die Franse taal in Gaboen}

Hierdie artikel bied 'n oorsig van die verskillende statusse wat aan die Franse taal gekoppel word in Gaboen, 'n Franssprekende land in Sentraal-Afrika. Dit openbaar 'n proses waardeur verskillende generasies Gaboenese toenemend Frans leer en gevolglik konseptualiseer as 'n tweede taal eerder as 'n vreemde taal. Verder is daar ook sommige sprekers wat Frans leer en konseptualiseer as 'n moedertaal of eerste taal, eerder as 'n tweede taal. Hierdie proses van herkonseptualisering is op een of ander wyse aangemoedig deur die taalbeleid van die koloniale administrasie en voortgesit sedert onafhanklikwording. Die uiteinde van hierdie proses is dat Frans, te midde van die inheemse tale, binne die Gaboenese taallandskap aanvaar is.

\section{Introduction}

This article provides a succinct review of the status of the French language in Gabon, a French-speaking country in the western part of Central Africa. Many studies have been done on French as it is spoken in Gabon. One could mention, among others, Couvert, (1982), Moussirou Mouyama (1984 \& 1986), Ogden (1984), Blanchon (1994), Pambou (1998), Tomba Moussavou (2001), Mindze M'Eyeghe (2001), Mavoungou (2002), Mouloungui Nguimbyt (2002), Ndinga-Koumba-Binza (2004), Ondo-Mebiame (2008), and Bounguendza (2010). A few of these studies such as Moussirou Mouyama (1984), Blanchon (1994), Pambou (1998), and NdingaKoumba-Binza (2004) have tried to circumscribe the status of French in this country. A study that specifically focused on the various statuses of French is that of Pambou (1998).

Pambou (1998:129-146) identified five statuses of French in Gabon, namely 2
1. second language
2. foreign language
3. mother-tongue, first language or initial language
4. real initial language

2 Pambou's terminology as translated from the French by the current author. 
5. official language and language of education

This identification by Pambou bears five issues. Firstly, some of the content and terminology used are not clearly explained. If (1), (2) and (5) are apparently comprehensible, the difference between (3) and (4) is unclear.

This is linked to the second issue, which is that each status should have a specific term. The third issue deals with the random order of his presentation of these five statuses. This order does not show how French has actually progressed to become the mother tongue of an important group within the Gabonese population as is the case at present. The following statement by Bounguendza (2008:13) seemingly shows the progressive status of French:

In Gabon, French has always been the language of the coloniser, thus, in a sense, the language of constraint, a language of assimilation and alienation, although it has afterward become a chosen language, a working language, but also the language of human rights. ${ }^{3}$

Fourthly, the institutional language status should not be confused with an individual's language status. At the institutional level, Gabon is a monolingual country since it has only one official language. However, at the individual level, many Gabonese citizens are bilingual or multilingual, having French as their initial, second or even third language. Finally, another oversight in Pambou's work is that he does not consider the fact that French, as it is spoken in Gabon, bears features of a local and national language.

This article intends to give an answer to each of the four issues identified in Pambou's study. Five statuses are also identified but presented in a progressive order. Each status is redefined, both historically and sociologically. Two of Pambou's statuses, (3) and (4), are combined into one status. Finally, a new status is added, namely local and national language, which is posited as the final status that French has reached in Gabon.

3 Bounguendza (2008:13; emphasis and translation - HSN-K-B):

Au Gabon, le français a toujours été la langue du colonisateur, donc en un sens, une langue de contrainte, une langue d'assimilation et d'aliénation, bien qu'elle soit devenue par la suite une langue choisie, une langue de travail, mais aussi la langue de droits de l'homme. 


\section{The foreign language}

As in all African francophone countries, the French language is a legacy of French and/or Belgian colonisation (Lafage, 1993:216). Therefore, it is a truism to say that French (belonging to the Latin branch of the Indo-European language family), is a foreign language in Gabon. However, there is always a historical reason why the population of an African country is labelled speakers of a European language.

French is in fact one of the eight West-European languages that became both the standard languages and the lingua francas of empires built by navigators, traders, soldiers, settlers, bureaucrats and religious missionaries in every corner of the world from the fifteenth century onward (McArthur, 1988:36; Ndinga-KoumbaBinza, 2006a:155).4

Thus, French was brought to Gabon via colonists and evangelists as shown in the study by Moussirou Mouyama (1986). In this situation, French is and might remain in Gabon just a foreign language - as it is in many other African countries.

It is also a foreign language because no native ethnic group has identified with French to the extent that, for example, members of the Yipunu, Civili, Fang and Yinzebi ethnic groups have identified with their languages. In fact, each Gabonese native group derives its name from the language that its members speak. Gabonese native languages are, therefore, ethnic languages (Ndinga-Koumba-Binza, 2004 \& 2005a: 72). For instance, the ethnic group Fang speaks Fang, the Bapunu speak Yipunu, the Bavili speak Civili, and the Banzebi speak Yinzebi, et cetera. This allows Pambou (1998:144) to assert that the French language does not belong to any ethnic group in Gabon, though it is the official language of the country.

At the same time, what can be called the French linguistic community or French ethnic group (approximately $10000^{5}$ people), is comprised of French citizens that have settled in Gabon. Very few

4 The seven other languages are Danish, Dutch, English, German, Italian, Portuguese and Spanish. But only English, French, Portuguese and Spanish remained colonial languages from the end of the slave trade until the twentieth century.

5 According to figures shown in the Gabonese online news network Gabon News, reporting on the French presidential elections in Gabon on 22 April 2007. 
have acquired Gabonese citizenship (mainly through marital bounds), but they are not culturally and formally regarded as a Gabonese ethno-linguistic group.

However, with its status of official and most widely used language, Lafage (1993:216) is of the view that in francophone Africa "nowhere is French truly a foreign language as in Ghana or Angola". 6 In fact, the language has acquired the status of second language in most African francophone countries.

\section{The second language}

Richards and Schmidt (2002:472) give two definitions for the notion of a second language, namely "in a broad sense, any language learned after one has learnt one's native language", and

when contrasted with foreign language, the term refers more narrowly to a language that plays a major role in a particular country or region though it may not be the first language of many people who use it.

Crystal (1999:299) adds to these definitions by indicating that a second language is "a language which is not a person's mother tongue, but which is learned in order to meet a communicative need".

These definitions are often linked to the geographical area of the speaker (Pambou, 1998:132; Cuq, 1991:124). For instance, Hungarian immigrants in France are said to speak French as a second language. In the same way, Latino immigrants in the United States are said to speak English as a second language.

Fully defined as such, these definitions may not be applicable to French in Gabon. Applying these definitions to French in Gabon would imply the following:

1. French would be the mother tongue of the native populations and, therefore, the second language of the non-native populations in Gabon (the same way French is the second language for Hungarians in France).

6 Ghana has English as its official language and Angola is a Portuguese-speaking country. 
2. Most Gabonese citizens speak an initial language which should be the national language (in the same way English is the second language in Botswana whereas Setswana is the initial language).

3. Non-French-speaking immigrants in Gabon speak French as a second language, e.g. Americans, Angolans, British, Dutch, Ghanaians, Italians, Nigerians, et cetera.

If point (3) is true without a doubt, points (1) and (2) are not exactly the case and need clarification. In fact, Gabon as a nation does not have any national language per se, which would have put French in the position of second language. Gabon is said to have about 40 native languages (Gordon, 2005:120; cf. also Lewis, 2009), yet none has the rank of "chief language of a nation state" (Crystal, 1999: 227), as French is to France, English to England, and Kinyarwanda to Rwanda. There is no language that is "a source or sign of identity" (Matthews, 1997:238) for the Gabonese population, nor is there a language that could bind Gabon as a nation state.

The Gabonese nation state has no main language besides its official language. French, the sole official language, is therefore the first or initial language of Gabon as a nation state. French, however, shows characteristics of a second language in individuals of the Gabonese population. Seen this way, French is the second language for three types of generations of Gabonese citizens, namely the colonial generation, the post-colonial generation, and the younger villager generation.

\subsection{The colonial generation}

The colonial generation refers to those Gabonese citizens who learnt French at school during the colonial era under the rule of France. This generation (at present aged from 60), learnt French under the French colonial language policy. This policy made French the sole language for communication in the essential domains of Gabonese society, namely education, economy, administration, media, literature, et cetera (Kwenzi-Mikala, 1990:122; Ndinga-KoumbaBinza, 2005a:66-67).

However, this colonial era generation has always had native Gabonese languages as their respective mother tongues or initial languages. They spoke French at school and their mother tongues at home (some of their parents could not speak French at all). The majority of this generation has retired from professional activities. It 
is known that they spoke French at work and in public domains, but they still predominantly use their mother tongues at home and at family gatherings. This was shown in the study by Idiata (2009) on endangered languages and language transmission in Gabon.

This is also the generation whose members learnt French under draconian circumstances with arduous efforts to suppress their own mother tongues (cf. Kwenzi Mikala, 1990:122-123), as the use of native languages was prohibited in schools and in all public sectors (Lafage, 1993:222; Kwenzi Mikala, 1990:123). This generation eventually became the first of the Gabonese elites, after which French became "the guarantee of rapid and often spectacular upward social mobility" (Lafage, 1993:220; cf. Bounguendza, 2008:14). Consequently, this generation of the Gabonese elite left this French language legacy to the post-colonial generation.

\subsection{The post-colonial generation}

There was intergenerational language transmission between the colonial generation and the post-colonial generation, the latter presently ranges in age from 45 to 60 . Most of these members heard spoken French for the first time from their parents (usually the fathers) who had been educated during the colonial era. However, as opposed to their fathers, these postcolonial members had formal French language instruction at school after the end of colonisation.

This generation did not experience any hardships when learning French and they restrained their initial languages. In addition, this generation grew up with the mindset that established French as the language of the elite and therefore the language of the future. The main feature of this generation, especially those in urban areas, is that they are the ones who allowed French to enter their homes with the support of their parents, who had received some education. They still speak their mother tongues on some occasions (when visiting rural areas, attending traditional ceremonies, etc.).

\subsection{The younger villager generation}

All villagers have French as a second language no matter the generation to which they belong. In fact, the medium of communication is mainly the vernacular language (the native language) of the community in rural zones. Most of the parents in village homes have not received any formal education. Therefore, their competence in French is likely to be insufficient for habitual communication. 
It is, however, important to emphasise that the younger generation in rural areas is different from that in urban areas, because of the fact that they have Gabonese native languages as their initial languages of communication. They only learn and speak French at school. They only speak their respective mother tongues at home and in their communities. The native mother tongue is sometimes used as a means of support at school alongside French in informal communication.

\section{The official language}

Moyo (2002:149) states that after the attainment of independence, most African governments found it easier to retain their colonial masters' languages as official language for functional purposes in official domains. Judge (1993:15) is of the same view when he mentions that

... some of the newly independent countries used French for pragmatic reasons, e.g. in order to communicate with the outside world and as a common language in what were usually multilingual countries.

This is what the Gabonese government did in 1960.

Since then, the Gabonese government has made a consistent effort to maintain the clarity of this status every time the Constitution of the Republic of Gabon (henceforth the Constitution) is revised. The Constitution (2000, Article 2, section 8) stipulates that "The Republic of Gabon adopts French as the official language". This one paragraph statement stipulates that French must serve as "the sole medium of instruction in the national educational system, and as the language of business, in civil administration and the media" (Nyangone Assam \& Mavoungou, 2000:255; cf. also Bounguendza, 2008: 13).

Pambou (1998:143) states that the Constitution and the National Anthem confirm the official nature of French by the fact that both are written in this language. This official status allows Gabon to be labelled a French-speaking country. In fact, although the Gabonese language landscape displays several native languages and a number of other foreign languages (Ndinga-Koumba-Binza, 2005b: 134; 2006a:154; 2007:113), none has ever been made official or been used for official purposes. As the sole official language, French had no difficulty in becoming the initial language of a large portion of the Gabonese population. 


\section{Mother tongue and initial language}

Linguists often understand the notion of mother tongue as the language one first acquires as a child (Crystal, 1999:119; Richards \& Schmidt, 2002:202). The mother tongue is also known as a person's initial language. It has been noted that French is increasingly becoming the mother tongue and the initial language of the younger generations in urban Gabon (Pambou, 1998:147; Ndinga-KoumbaBinza, 2005a:72 \& 2005b:141; Idiata, 2008:85; cf. Blanchon, 1994). In fact, studies by Ntong Amvame (1984), Bouché (1998), Mbondzi (1998), Ompoussa (1998), Itembo (1999) and Mouloungui Nguimbyt (2002) have shown that pupils of various ages and grades at schools learn French more efficiently than any other Gabonese language. Idiata (2008:200 \& 2009:126) has also noted that some pupils do not speak any of the Gabonese native languages at all. One of the reasons for this phenomenon (i.e. French being the mother tongue of younger generations) is cross-ethnic marriages.

In fact, many couples of mixed ethnicity prefer French rather than Gabonese native languages as the code for better communication within the family. Children from a family of this kind have no choice but to acquire French as their first language. The children learn the language at home from the parents before they even get to school, therefore lessening the chances of learning any of the Gabonese native languages.

Intense urbanisation as a result of various rural exoduses threw together all the different ethnic groups of the state in huge urban centres (Ndong Mba, 2003:38; Lafage, 1993:225). This urbanisation is also to be considered as a cause for French being the initial language of Gabonese younger generations. In fact, "in certain urban contexts there is a large degree of learning by contact at an early age" (Lafage, 1993:216). Thus, French is not only the lingua franca, but mainly the common language for various communities (both native and foreign) from different linguistic backgrounds. For example, Libreville, the capital city, has "experienced rapid growth over the past thirty years in migration ... from various regions of Gabon and from neighbouring countries" (Ndinga-Koumba-Binza, 2006b:50).

The demographic profile drawn for Libreville shows that the strongest concentration of the national population (approximately 40\%) is set in Libreville and its suburbs (Idiata, 2008:89; Ndinga-KoumbaBinza, 2006b; Ndong Mba, 2004; Bissielo, 2001). When considering other cities within the country, the information shows that $73 \%$ of the 
population lives in urbanised zones (Idiata, 2008:87), and therefore makes use of French for social communication. In this case, when learning and practising the art of communication, the children are not influenced by the families into which they are born but rather by the social milieu in which they grow up (cf. Pambou, 1998:138).

The third reason why French is increasingly becoming the mother tongue of younger generations, is that native languages have lost their value. From the colonial era, these languages have been strongly attacked by the presence of French and the severe colonial French language policy.

This policy prohibited the use of any native language in public domains (Kwenzi-Mikala, 1990:122) and ultimately led to the decay of native languages, which also have a very limited number of speakers (a population of 1,5 million for 40 languages). This policy aimed, among other things, to promote French and resulted in it becoming the language of the elite and of development and social mobility. All of this is set in a context where the current language policy - only a one-paragraph statement in the Constitution - does not provide for the promotion of native languages.

\section{National and local language}

Gabon is linguistically diverse, yet there is no native language which is genuinely dominant at the national level. Very few native languages are regionally dominant in their provinces of origin (Ndinga-Koumba-Binza, 2007:108-110), for example, Fang in the provinces of Estuaire, Moyen-Ogooué, Ogooué-Ivindo and WoleuNtem; Yipunu in the provinces of Ngounié, Nyanga and MoyenOgooué; and Yinzebi in the provinces of Ogooué-Lolo, Ngounié and Haut-Ogooué.

Lafage (1993:224) depicts the real situation in Gabon.

Because of natural obstacles such as virgin forests, rivers and mountains, languages have split up into numerous dialects which are sometimes understood by very few people. Yet a modern state requires intercommunication. (Lafage, 1993:224.)

This ineed for intercultural or interethnic communication between the various ethnic groups is, in the absence of a dominant native language at the national level or a lingua franca (such as Lingala in the Democratic Republic of the Congo, or Sango in the Republic of Central Africa), also an important reason why the Republic of Gabon had to adopt French as its official language. 
The need for intercultural communication is crucial in urban areas. As indicated earlier, Gabon is known to have one of the highest rates of urbanisation in Africa (cf. Ndinga-Koumba-Binza, 2006b:4850; Idiata, 2008:87). This adds to the monolingualism, essentially in French, of Gabonese cities and de facto of the entire country as it is theorised by Calvet $(1994 ; 2000)$.

Ndinga-Koumba-Binza $(2004 ; 2005 a: 71 ; 2007: 111)$ points out that the constitutional provision actually nationalises French as a Gabonese language (Couvert, 1982; Ogden, 1984). Moreover, French nowadays happens to be the only dominant language at the national level (Ndinga-Koumba-Binza, 2007:107-108). This view is also revealed in the volumes of Ethnologue: languages of the world (published and regularly updated by the Summer Institute of Linguistics), which very often includes French in the census of Gabonese languages (cf. Lewis, 2009; Gordon, 2005:120). In his bibliographic updates on Gabon, Gardinier (1992) also refers to French as one of the Gabonese languages but also as the only language of national status in terms of geographic domains of use. In fact, French is the only language that is largely spoken in every single province of the Gabonese territory.

While drawing up the Gabonese language landscape (GLL), NdingaKoumba-Binza (2005b:134; 2007:113) indicated that the first main branch of the GLL is made up of French and Gabonese native languages under the heading of "Local languages".7 Ndinga-KoumbaBinza (2004; 2005a:72; 2007:111) asserts that French bears all the characteristics of a national language in Gabon.

This view agrees with the personal opinion often expressed by the late President Omar Bongo Ondimba, 8 who wrote that French was the firm foundation of national unity in the country (Bongo Ondimba, 1998). This led Bounguendza (2008:13) to point out that the use of French is a matter of national politics.

$7 \quad$ The second main branch is under the heading "Foreign languages", including international languages such as English and Spanish as well as smaller languages from various immigrants.

8 Omar Bongo Ondimba ruled Gabon for 42 years until his death in June 2009. 
Furthermore, on a live national TV show, 9 while speaking to the crowd in the eastern Gabonese city of Koulamoutou (a city in which Yinzebi is primarily spoken), Omar Bongo Ondimba made the following statement:

This is my home. ${ }^{10}$ I would love to speak in Yinzebi, but under the circumstances let me speak in our national language which is French. (Translated - HSN.)

This statement roused no reaction from Gabonese linguists at Omar Bongo University in Libreville. It is therefore not known whether they agree or disagree with the statement.

There may be many reasons for this lack of reaction from the academic linguists. In my view, the first reason was that Omar Bongo Ondimba's views and decisions were hardly questioned or contested. This was due to the dictatorial political regime he had put in place. Therefore, this particular context of Gabon made the statement acceptable and the linguists could not express their disapproval thereof. The second reason is that, as seen earlier in this section, French has gained a national status by default due to the country's need for interethnic communication. Thus, Bongo Ondimba's statement did not need any response as it expressed an accurate description of Gabon's language situation.

\section{Conclusion}

The "gabonisation" of the French language is nowadays a truism. This article has attempted to show this process by describing the different statuses the language bears in Gabon. French has supplanted native Gabonese languages in all domains of life (cf. Idiata, 2008 \& 2009), and has thus become the national language of Gabon not only by default, but also on a political basis. The language has become a "Gabonese language" and it is no longer a foreign language per se. It is used in all functions and offices of the State and entirely in the educational and economic systems of the country.

9 Broadcast live by Radiodiffusion Télévision Gabonaise, première chaîne (RTG 1) on 4 December 2006.

10 Omar Bongo Ondimba's mother tongue was Teke. Born in Lewaï (now Bongoville) in the Gabonese province of Haut-Ogooué, he grew up in Brazzaville in the Republic of the Congo. His statement was to identify himself with the population of Koulamoutou, the main city of the province of OgoouéLolo. The latter province is dominated by the Yinzebi-speaking community. 
The Gabonese have adopted French and the majority of the population still endorses French to the detriment of their native languages (cf. Ndinga-Koumba-Binza, 2004; Idiata, 2008; 2009). One of the outcomes of this adoption is the interchange at the cultural level between the native languages and the adopted language (Mavoungou et al., 2003:151-152).

It should be noted that the gabonisation of French does not occur without expense to the language itself. French has become Gabonese as well in both its structure and its lexicon. This is reflected by the many Gabonese-specific forms of speaking and many neologisms (cf. Ondo-Mebiame, 2008:200; Mavoungou, 2002:234-248). These forms are included in Gabonese French dictionaries such as Bounguendza (2008 \& 2010) and Ditougou (2009). However, these forms and neologisms have no status in the standard language and are used neither in education nor in formal communication.

\section{List of references}

BISSIELO, A. 2001. The urban space as field of analysis of poverty: the case of Libreville. Paper presented at the Congress of the South African Association of Sociology, University of Pretoria, 3-6 July 2001.

BLANCHON, J.A. 1994. Gabon: language situation. (In Asher, R.E., ed. The Encyclopedia of Language and Linguistics. Vol. 3. Oxford: Pergamon. p. 1341-1343.)

BONGO ONDIMBA, O. 1998. Les chances du Gabon pour l'an 2000, le chemin du futur. Libreville: Multipress.

BOUCHE, K. 1998. Langues et identité culturelle des jeunes librevillois de 15 à 30 ans: une enquête de terrain. Paris: Université Sorbonne Nouvelle. (M.A. dissertation.)

BOUNGUENDZA, E.D. 2008. Dictionnaire des Gabonismes. Paris: L'Harmat$\tan$.

BOUNGUENDZA, E.D. 2010. Diagnostic du français du Gabon. Libreville: Les Editions Ntsame.

CALVET, L-J. 1994. Les voix de la ville: introduction à la sociolinguistique urbaine. Paris: Payot \& Rivages.

CALVET, L-J. 2000. La ville et la gestion in vivo des situations linguistiques. (In Calvet, L-J. \& Moussirou Mouyama, A., eds. Le plurilinguisme urbain. Paris: Institut de Francophonie/Diffusion Didier Erudition. p. 11-30.)

COUVERT, C. 1982. La langue Française en République Gabonaise. Paris: Haut Comité de la Langue Française.

CRYSTAL, D. 1999. The Penguin Dictionary of Language. 2nd ed. Harmondsworth: Penguin.

CUQ, J.P. 1991. Le Français langue seconde, des origines d'une notion et implications didactiques. Paris: Hachette.

DITOUGOU, L. 2009. On est ensemble: 852 mots pour comprendre le Français du Gabon. Libreville: Editions Raponda-Walker. 
GABON. 2000. Constitution of the Republic of Gabon. Libreville: Direction des Publications Officielles.

GARDINIER, D.E. 1992. Gabon. World bibliographical series. Vol. 149. New York: Clio.

GORDON, R.G. 2005. Ethnologue: languages of the world. 15th ed. Dallas: Summer Institute of Linguistics.

IDIATA, D.F. 2008. Le français et les langues Gabonaises, du partenariat au linguicide: une analyse des données des enfants tirées du contexte de la ville de Libreville. Revue gabonaise des sciences du langage, 3:85-208.

IDIATA, D.F. 2009. Langues en danger et langues en voie d'extinction au Gabon. Paris: L'Harmattan.

ITEMBO, G. 1999. Normes endogènes du Français, problèmes identitaires et institution scolaire à Libreville. Libreville: Université Omar Bongo. (M.A. dissertation.)

JUDGE, A. 1993. French: a planned language? (In Sanders, C., ed. French today: language in its social context. Cambridge: Cambridge University Press. p. 7-26.)

KWENZI-MIKALA, J.T. 1990. Quel avenir pour les langues Gabonaises? Revue Gabonaise des sciences de l'homme, 2:121-124.

LAFAGE, S. 1993. French in Africa. (In Sanders, C., ed. French today: Ianguage in its social context. Cambridge: Cambridge University Press. p. 215-238.)

LEWIS, M.P. 2009. Ethnologue: languages of the world. 16th ed. Dallas: Summer Institute of Linguistics. Online version: http://www.ethnologue. com Date of access: 5 May 2010.

MATTHEWS, P.H. 1997. The Concise Oxford Dictionary of Linguistics. Oxford: Oxford University Press.

MAVOUNGOU, P.A. 2002. Vers un dictionnaire du Français du Gabon. (In Emejulu, J.D., ed. Eléments de lexicographie Gabonaise. Vol. 2. New York: Jimacs-Hillman. p. 230-262.)

MAVOUNGOU, P.A., AFANE OTSAGA, T. \& MIHINDOU, G-R. 2003. The reproduction of cultural aspects in dictionaries in French and the Gabonese languages. Lexikos, 13:133-153.

MBONDZI, J.Y. 1998. La syntaxe du Français des élèves du cours moyen de Libreville: cas de l'école Martine Oulabou. Libreville: Université Omar Bongo. (M.A. dissertation.)

MCARTHUR, T. 1988. Words of reference: lexicography, learning and language from the clay tablet to the computer. Cambridge: Cambridge University Press.

MINDZE M'EYEGHE, J. 2001. Approches de quelques particularités lexicales du Français parlé au Gabon. Libreville: Université Omar Bongo. (M.A. dissertation.)

MOULOUNGUI NGUIMBYT, F.V. 2002. De la variation dialectale en Français du Gabon. Libreville: Université Omar Bongo. (M.A. dissertation.)

MOUSSIROU MOUYAMA, A. 1984. Langue Française au Gabon: contribution sociolinguistique. Paris: Université René Descartes. (Ph.D. thesis.)

MOUSSIROU MOUYAMA, A. 1986. L'introduction de la langue Française au Gabon. Libreville: Université Omar Bongo. (Annales de l'Université Omar Bongo du Gabon: Série Lettres, Droit, Sciences et Médecine, 55-63.) 
MOYO, T. 2002. Mother tongues versus an ex-colonial language as media of instruction and the promotion of multilingualism: the South African experience. South African journal of African languages, 22(2):149-160.

NDINGA-KOUMBA-BINZA, H.S. 2004. Le statut socio-politique du Français et la promotion des langues locales au Gabon. Paper presented at the 18th International Conference of the Association of French Studies in Southern Africa (AFSSA) held by the French Section of the Department of Modern Foreign Languages at the University of Stellenbosch, 4-11 September 2004.

NDINGA-KOUMBA-BINZA, H.S. 2005a. Politique linguistique et éducation au Gabon: un état des lieux. Journal of education, 4(1):65-78.

NDINGA-KOUMBA-BINZA, H.S. 2005b. Considering a lexicographic plan for Gabon within the Gabonese language landscape. Lexikos, 15:132-150.

NDINGA-KOUMBA-BINZA, H.S. 2006a. English in French-speaking African countries: the case of Gabon. (In Arua, A.E., Bagwasi, M.M., Sebina, T. \& Seboni, B., eds. The study and use of English in Africa. London: Cambridge Scholars Press. p. 152-164.)

NDINGA-KOUMBA-BINZA, H.S. 2006b. Demographic profiles of Libreville and Lomé. (In Bekker, S. \& Leildé, A., eds. Reflections on identity in four African cities. Stellenbosch: African Minds. p. 45-50.)

NDINGA-KOUMBA-BINZA, H.S. 2007. Gabonese language landscape: survey and perspectives. South African journal of African languages, 27(1):97116.

NDONG MBA, J.C. 2003. Activités commerciales et environnement urbain au Gabon. iBoogha, 7:27-47.

NDONG MBA, J.C. 2004. Libreville, Owendo: atlas de l'Afrique - Gabon. Paris: Les Editions J.A.

NTONG AMVAME, H. 1984. Langue Française et langue Gabonaise: esquisse d'une étude contrastive pour une orientation pédagogique. Libreville: Université Omar Bongo. (M.A. dissertation.)

NYANGONE ASSAM, B. \& MAVOUNGOU, P.A. 2000. Lexicography in Gabon: a survey. Lexikos, 10:252-274.

OGDEN, J. 1984. French in Gabon. Contemporary French civilization, 8:339348.

OMPOUSSA, V. 1998. Problèmes de maîtrise de ponctuation chez les élèves du cours moyen élémentaire à Libreville: cas de E.A.-ENS/A. Libreville: Université Omar Bongo. (M.A. dissertation.)

ONDO-MEBIAME, P. 2008. La formation des néologismes en Français Gabonais: analyse d'un corpus tiré du journal Le Scribouillard. Revue Gabonaise des sciences du langage, 3:151-200.

PAMBOU, J.A. 1998. Le Français au Gabon: une langue à multiples statuts. iBoogha, 2:127-149.

RICHARDS, J.C. \& SCHMIDT, R. 2002. Longman Dictionary of Language Teaching and Applied Linguistics. 3rd ed. London: Longman.

TOMBA MOUSSAVOU, F. 2001. Les réalisations de séquences de consonnes en Français de Libreville. Libreville: Université Omar Bongo. (M.A. dissertation.)

\section{Web sites}

www.gabonews.ga Date of access: 26 Apr. 2007. 


\section{Key concepts:}

French

Gabon

language landscape

language policy

language status

\section{Kernbegrippe:}

\section{Frans}

Gaboen

taalbeleid

taallandskap

taalstatus 